\title{
Post-Stroke Quality of Life Outcomes After Instituting New Stroke Care Quality Indicators
}

\author{
Khaled Awawdi, Carmel Armon, Itzhak Kimiagar, Mahdi Tarabeih and Riad Abu Rakia
}

\section{ABSTRACT}

Background: In 2013 the Israel Ministry of Health identified the care and treatment of acute cerebral ischemic stroke as failing to achieve expected standards. The Ministry decided to raise standards by defining and instituting, nationwide, a battery of linked care quality indicators to be applied across all relevant facilities and contexts. Five indicators were selected for five key junctures in the AIS care process.

Methods: This paper presents and analyses the effects of the implementation of these new care quality indicators on the post-discharge quality of life outcomes of Israeli stroke sufferers. The patient sample comprises patients from Israel's Central region, where stroke care provision and access is relatively high, and from the peripheral North region, where provision and access are limited.

Results: Those who were not treated with thrombolytic treatment and/or cerebral blood vessel catheterization, those who suffered severer strokes, women, the older age groups, non-Jews and North region residents display significantly worse physical functioning outcomes and worse quality of life outcomes on all indicators.

Conclusions: Stroke care access and provision disparities translate into significantly higher rates of post-discharge disability, impaired physical and social functioning, and a lower quality of life.

The effectiveness of healthcare improvement by the deployment of care indicators is closely associated with the lifestyle, socio-demographic and socioeconomic status of different population groups. The effective implementation of quality care indicators also relies heavily on closing the access and provision gaps between the populations living in central and peripheral areas. Two obvious directions for action are to expand and improve the rehabilitation care network and to combat the age discrimination in hospital stroke treatment.

Keywords: care pathways, disability, ischemic stroke, quality indicators, quality of life, sociodemographic discrimination.

\section{BACKGROUND}

In 2013 the Israel Ministry of Health began to identify issues, illnesses, and illness states where current medical practice was failing to achieve expected standards. The third such illness state identified was the care and treatment of acute cerebral ischemic stroke (AIS). As for the previous illness states identified, the Ministry decided to raise standards by instituting, nationwide, a battery of linked care quality indicators to be applied across all relevant facilities and contexts. Five indicators were selected for five key junctures in the AIS care process [1]:

Pre-hospital (ambulance) phase:

1. Standard assessment for stroke when ischemic cerebral stroke is suspected.

2. Advance warning sent to hospital when ischemic cerebral stroke is suspected.
Published Online: January 8, 2021

ISSN: 2593-8339

DOI: $10.24018 /$ ejmed.2021.3.1.641

Dr. Khaled Awawdi *

Israel Academic College, Israel.

(e-mail: awawdi.h@iac.ac.il)

Prof. Carmel Armon

Chairman, Department of Neurology,

Shamir (Assaf Harofeh) Medical Center, Israel.

(e-mail: carmon@ ${ }^{\circledR}$ shamir.gov.il)

Dr. Itzhak Kimiagar

Stroke unit manager, Shamir (Assaf

Harofeh) Medical Center, Israel.

(e-mail: itzhakK@shamir.gov.il)

Mahdi Tarabeih

RN PhD, Senior lecturer, Faculty of Nursing Sciences, Tel Aviv-Jaffa Academic College, Israel.

(e-mail: arabeih1969@gmail.com)

Riad Abu Rakia

$\mathrm{RN}, \mathrm{PhD}$, Senior lecturer, and Head, Home Palliative Care dpt., School of Nursing Sciences, Tel Aviv Academic College, Israel.

(e-mail: riad66@ hotmail.com)

*Corresponding Author
Hospital phase:

3. CT/MRI scan within 25 minutes of cerebral stroke patient's admission.

4. Thrombolytic treatment (intravenous rTPA VI) to stroke patients who are within 4.5 hours of symptom onset and/or cerebral blood vessel catheterization (CAC) within 8 hours of symptom onset, provided that the patient was admitted to hospital within a maximum of 3.5 hours from symptom onset.

Rehabilitation phase:

5. Administer FIM-in functional assessment tests on admission to rehabilitation and FIM-out tests on discharge from rehabilitation.

This paper presents and analyses the effects of the implementation of these five new care quality indicators on the post-discharge quality of life outcomes of stroke patients. The sample for this study comprised patients from Israel's Central region where stroke care provision and access is 
relatively high, and from the peripheral North region, where provision and access are limited. (The source tables are to be found in the Supplemental Digital Content file (SDC).

\section{RESULTS}

The stand-out findings of SDC Tables 1-2, which quantify post-stroke physical functioning outcomes, are:

- Whereas half the patients who were administered rTPA/CAC within the effective time-window returned to their pre-AIS functioning level only $16 \%$ of those who did not receive $\mathrm{rTPA} / \mathrm{CAC}$ did so.

- Few of the two younger age groups suffered severe disfunction and many more younger patients than the older returned to their pre-AIS functioning level.

- Far more Jews returned to their pre-AIS functioning level and far fewer suffered re-hospitalization despite being older than the Israeli Arab stroke patient population. 56\% of Central region residents (a mainly Jewish population) returned to their pre-AIS functioning level but only $27 \%$ of North region residents.

- $74 \%$ of patients with primary schooling only - most will be Israeli Arabs - suffered moderate to severe functional impairment while those with higher schooling had much better functioning outcomes.

- Women stroke patients had more re-hospitalizations although the difference from the men is not statistically significant.

The stand-out findings of SDC Tables 3-4, which quantify post-stroke quality of life (QoL) outcomes, are:

- Those who were not treated with rTPA/CAC, those who suffered severer strokes, women, the older age groups, non-Jews and North region residents displayed significantly worse outcomes on all thirteen QoL indicators.

- Some QoL components attract higher perceived scores than others: bodily pain, for instance, attracts much higher scores across all patient groups than other components.

- The less severe the stroke the better off the patient on all indicators, especially on Functioning level, Physical role, General Health and Emotional Role, demonstrating the close linkage between physical health and perceived QoL.

TABLE 1: THE CHANGE IN FUNCTIONING LEVEL FROM PRE-AIS TO THE 3-MONTH FOLLOW-UP BY RECEIPT/NON-RECEIPT OF RTPA/CAC, SOCIODEMOGRAPHIC/ SOCIOECONOMIC VARIABLES AND STROKE SEVERITY (PERCENTAGES ONLY)

\begin{tabular}{|c|c|c|c|c|}
\hline & $\begin{array}{l}\text { Functioning declines } \\
\text { severely }\end{array}$ & $\begin{array}{l}\text { Functioning declines } \\
\text { moderately }\end{array}$ & $\begin{array}{l}\text { Functioning returns to } \\
\text { pre-CVA level }\end{array}$ & All \\
\hline Got rTPA/CAC & 13.7 & 35.6 & 50.7 & $100 \%$ \\
\hline $\begin{array}{l}\text { Did not get } \\
\text { rTPA/CAC }\end{array}$ & 21.6 & 62.2 & 16.2 & $100 \%$ \\
\hline$\chi^{2}(2)$ & & $12.29(\mathrm{p}=.002)$ & & \\
\hline \multicolumn{5}{|l|}{ Gender: } \\
\hline Male & 16.7 & 47.0 & 36.4 & $100 \%$ \\
\hline Female & 15.9 & 40.9 & 43.2 & $100 \%$ \\
\hline$\chi^{2}(2)$ & & $0.54(\mathrm{p}=.763)$ & & \\
\hline \multicolumn{5}{|l|}{ Age group: } \\
\hline $30-59$ & 8.3 & 44.4 & 47.2 & $100 \%$ \\
\hline $60-69$ & 13.3 & 46.7 & 40.0 & $100 \%$ \\
\hline $70-79$ & 22.2 & 50.0 & 27.8 & $100 \%$ \\
\hline $80+$ & 26.9 & 38.5 & 34.6 & $100 \%$ \\
\hline$\chi^{2}(6)$ & & -- & & \\
\hline \multicolumn{5}{|l|}{ Ethnicity: } \\
\hline Jewish & 14.5 & 33.9 & 51.6 & $100 \%$ \\
\hline Non-Jewish & 19.6 & 56.5 & 23.9 & $100 \%$ \\
\hline$\chi^{2}(2)$ & & $8.61(\mathrm{p}=.014)$ & & \\
\hline \multicolumn{5}{|l|}{ Schooling: } \\
\hline Primary & 19.1 & 55.3 & 25.5 & $100 \%$ \\
\hline Secondary & 15.6 & 24.4 & 60.0 & $100 \%$ \\
\hline Academic & 11.1 & 66.7 & 22.2 & $100 \%$ \\
\hline$\chi^{2}(4)$ & & $16.38(\mathrm{p}=.003)$ & & \\
\hline \multicolumn{5}{|c|}{ Location of treating hospital: } \\
\hline Centre & 15.2 & 28.3 & 56.5 & $100 \%$ \\
\hline North & 17.2 & 56.3 & 26.6 & $100 \%$ \\
\hline$\chi^{2}(2)$ & & $10.91(\mathrm{p}=.004)$ & & \\
\hline \multicolumn{5}{|l|}{ Stroke severity } \\
\hline 0 Low & 10.5 & 39.5 & 50.0 & $100 \%$ \\
\hline 1 & 13.5 & 50.0 & 36.5 & $100 \%$ \\
\hline 2 & 23.1 & 46.2 & 30.8 & $100 \%$ \\
\hline 3 High & 57.1 & 28.6 & 14.3 & $100 \%$ \\
\hline$\chi^{2}(6)$ & & -- & & \\
\hline Total & 16.4 & 44.5 & 39.1 & $100 \%$ \\
\hline
\end{tabular}

- $\quad$ ' $=$ Cells too small to calculate $\chi^{2}$.

- Functioning level according to Modified Ranking Scale for Neurological Disability. 
TABLE 2: RE-HOSPITALIZATION AND OTHER PHYSICAL PROBLEMS DURING THE THREE MONTHS AFTER HOSPITAL DISCHARGE BY RECEIPT/NON-RECEIPT OF RTPA/CAC, SOCIODEMOGRAPHIC/ SOCIOECONOMIC VARIABLES, AND STROKE SEVERITY (PERCENTAGES ONLY)

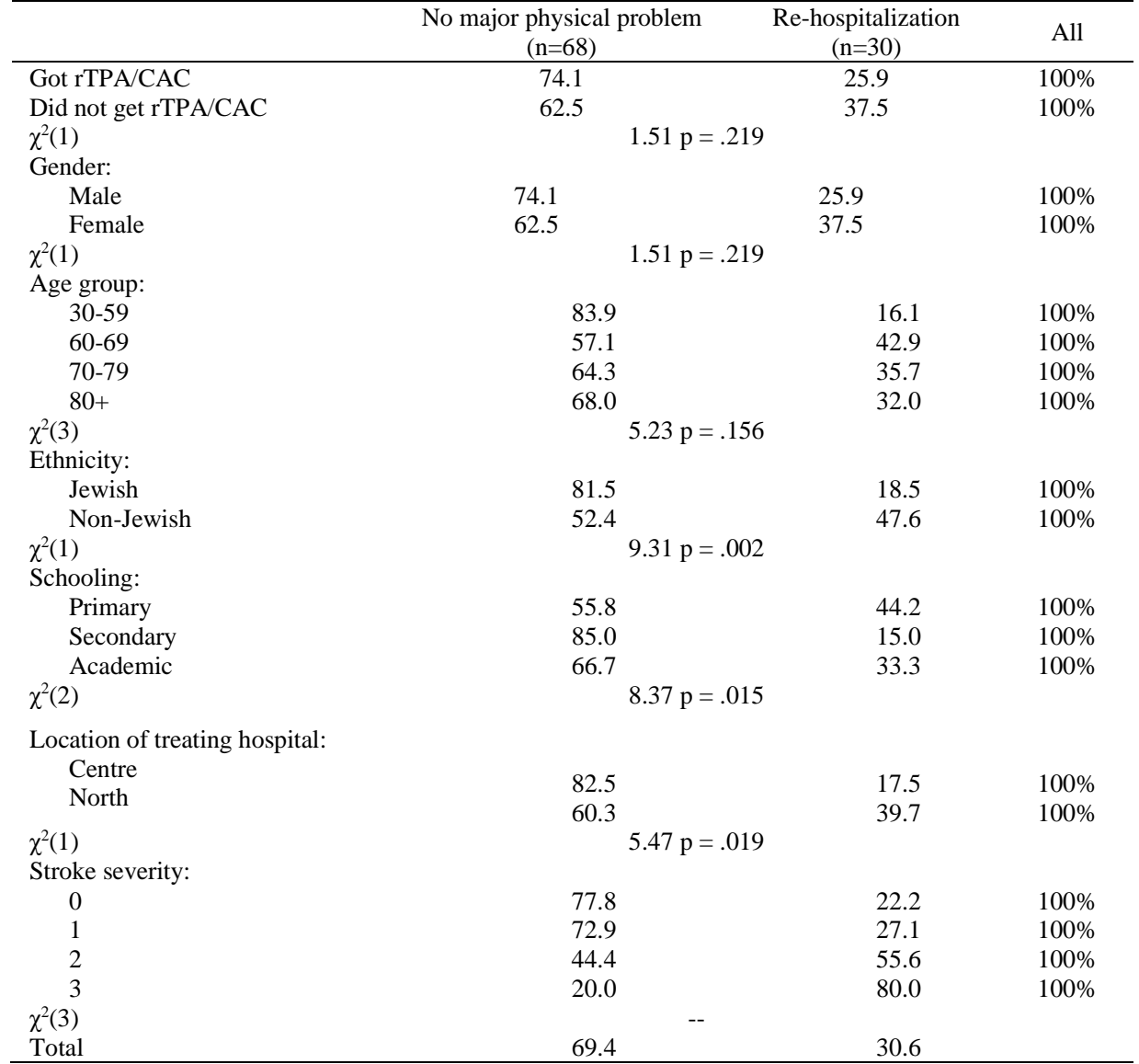

NB. '- ' marks cells too small to calculate $\chi^{2}$.

TABLE 3: EFFECTS ON RESPONDENT'S OVERALL WELLBEING (IN THE MONTH BEFORE THE FOLLOW-UP INTERVIEW) OF LIVING CONDITIONS, ACCESS TO PUBLIC TRANSPORT AND PUBLIC INSTITUTIONS AND PARTICIPATION IN SOCIAL ACTIVITIES BY RECEIPT/NON-RECEIPT OF RTPA/CAC, SOCIODEMOGRAPHIC/

\begin{tabular}{|c|c|c|c|c|c|}
\hline \multicolumn{6}{|c|}{ SOCIOECONOMIC VARIABLES, AND STROKE SEVERITY } \\
\hline & $\begin{array}{l}\text { Living } \\
\text { conditions } \\
\mathrm{M}(\mathrm{SD})\end{array}$ & $\begin{array}{l}\text { Access to public } \\
\text { transport } \\
\mathrm{M}(\mathrm{SD})\end{array}$ & $\begin{array}{l}\text { Access to public } \\
\text { institutions } \\
\mathrm{M}(\mathrm{SD})\end{array}$ & $\begin{array}{l}\text { Access to health } \\
\text { services } \\
\text { M (SD) }\end{array}$ & $\begin{array}{c}\text { Participation in social } \\
\text { activities } \\
\text { M (SD) }\end{array}$ \\
\hline Got rTPA/CAC & $2.10(1.32)$ & $2.25(1.34)$ & $2.19(1.31)$ & $1.99(1.27)$ & $2.19(1.39)$ \\
\hline Did not get rTPA/CAC & $2.61(1.37)$ & $2.95(1.27)$ & $2.97(1.28)$ & $2.84(1.30)$ & $3.13(1.17)$ \\
\hline $\mathrm{p}$ & .522 & .108 & .036 & .017 & .007 \\
\hline Male & $2.02(1.14)$ & $2.14(1.12)$ & $2.14(1.11)$ & $2.00(1.14)$ & $2.26(1.23)$ \\
\hline Female & $2.64(1.55)$ & $3.00(1.51)$ & $2.93(1.53)$ & $2.69(1.52)$ & $2.89(1.53)$ \\
\hline $\mathrm{p}$ & .023 & .002 & .004 & .012 & .023 \\
\hline $30-59$ & $1.69(1.09)$ & $1.97(1.18)$ & $1.86(1.13)$ & $1.69(1.17)$ & $2.11(1.19)$ \\
\hline $60-69$ & $2.10(1.18)$ & $2.27(1.14)$ & $2.23(1.17)$ & $2.13(1.07)$ & $2.4(1.38)$ \\
\hline $70-79$ & $2.67(1.37)$ & $3.06(1.55)$ & $2.89(1.41)$ & $2.67(1.46)$ & $2.56(1.54)$ \\
\hline $80+$ & $2.96(1.51)$ & $3.04(1.37)$ & $3.22(1.37)$ & $2.96(1.43)$ & $3.15(1.38)$ \\
\hline $\mathrm{P}$ & $<.001$ & .003 & $<.001$ & $<.001$ & .028 \\
\hline \multicolumn{6}{|l|}{ Ethnicity: } \\
\hline Jewish & $2.02(1.26)$ & $2.24(1.33)$ & $2.26(1.30)$ & $2.05(1.30)$ & $2.26(1.32)$ \\
\hline Non-Jewish & $2.62(1.44)$ & $2.83(1.36)$ & $2.74(1.39)$ & $2.60(1.38)$ & $2.87(1.44)$ \\
\hline 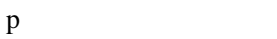 & .025 & .025 & .064 & .036 & .022 \\
\hline Primary & $2.85(1.40)$ & $3.15(1.35)$ & $3.06(1.42)$ & $2.81(1.39)$ & $3.02(1.41)$ \\
\hline Secondary & $1.73(1.16)$ & $1.87(1.14)$ & $1.93(1.12)$ & $1.76(1.19)$ & $2.02(1.27)$ \\
\hline Academic & $2.06(1.11)$ & $2.28(1.07)$ & $2.17(1.04)$ & $2.17(1.04)$ & $2.39(1.19)$ \\
\hline-5 & $<.001$ & $<.001$ & $<.001$ & $<.001$ & .002 \\
\hline Centre & $2.02(1.32)$ & $2.28(1.42)$ & $2.26(1.42)$ & $2.04(1.35)$ & $2.22(1.41)$ \\
\hline North & $2.45(1.36)$ & $2.63(1.29)$ & $2.60(1.28)$ & $2.45(1.32)$ & $2.72(1.34)$ \\
\hline $\mathrm{p}$ & .104 & .183 & .193 & .120 & .058 \\
\hline \multicolumn{6}{|l|}{ Stroke severity: } \\
\hline 0 (Low) & $1.74(1.08)$ & $2.00(1.21)$ & $2.03(1.17)$ & $1.92(1.17)$ & $2.00(1.25)$ \\
\hline 1 & $2.12(1.13)$ & $2.38(1.21)$ & $2.31(1.20)$ & $2.08(1.17)$ & $2.46(1.29)$ \\
\hline 2 & $3.36(1.60)$ & $3.43(1.45)$ & $3.43(1.50)$ & $3.36(1.50)$ & $3.36(1.39)$ \\
\hline 3 (High) & $4.14(1.07)$ & $4.00(1.15)$ & $4.00(1.15)$ & $3.57(1.51)$ & $4.00(1.15)$ \\
\hline 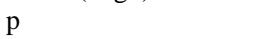 & $<.001$ & $<.001$ & $<.001$ & $<.001$ & $<.001$ \\
\hline Total & $2.27(1.35)$ & $2.49(1.35)$ & $2.46(1.35)$ & $2.28(1.34)$ & $2.51(1.39)$ \\
\hline
\end{tabular}

This table was composed in order to explore the issue of social disability. It tabulates the responses to the question: Over the last four weeks, to what extent has your overall situation been negatively affected by your living conditions, by your access to public transport, to public institutions and to health services, and by your participation in social activities? 
TABLE 4: PERCEIVED QUALITY-OF-LIFE COMPONENTS IN THE THREE MONTHS AFTER HOSPITAL DISCHARGE BY RECEIPT/NON-RECEIPT OF RTPA/CAC, SOCIODEMOGRAPHIC/ SOCIOECONOMIC VARIABLES, AND STROKE SEVERITY

\begin{tabular}{|c|c|c|c|c|c|c|c|c|c|}
\hline & $\begin{array}{c}\text { Physical } \\
\text { functioning } \\
\text { M (SD) }\end{array}$ & $\begin{array}{l}\text { Physical } \\
\text { role } \\
\mathrm{M}(\mathrm{SD})\end{array}$ & $\begin{array}{l}\text { Bodily } \\
\text { pain } \\
\text { M (SD) }\end{array}$ & $\begin{array}{l}\text { General } \\
\text { health } \\
\text { M (SD) }\end{array}$ & $\begin{array}{l}\text { Vitality } \\
\text { M (SD) }\end{array}$ & $\begin{array}{c}\text { Social } \\
\text { functioning } \\
\mathrm{M}(\mathrm{SD})\end{array}$ & $\begin{array}{c}\text { Emotional } \\
\text { role } \\
\mathrm{M}(\mathrm{SD})\end{array}$ & $\begin{array}{l}\text { Mental } \\
\text { health } \\
\text { M (SD) }\end{array}$ & $\begin{array}{c}\text { Total quality } \\
\text { of life } \\
\text { M (SD) }\end{array}$ \\
\hline Got rTPA/CAC & $\begin{array}{c}53.77 \\
(34.02)\end{array}$ & $\begin{array}{c}56.68 \\
(34.05)\end{array}$ & $\begin{array}{c}77.46 \\
(25.41)\end{array}$ & $\begin{array}{c}61.58 \\
(25.49)\end{array}$ & $\begin{array}{c}60.62 \\
(24.27)\end{array}$ & $\begin{array}{c}62.67 \\
(29.50)\end{array}$ & $\begin{array}{c}58.22 \\
(31.75)\end{array}$ & $\begin{array}{c}66.61 \\
(23.67)\end{array}$ & $\begin{array}{c}62.17 \\
(22.17)\end{array}$ \\
\hline $\begin{array}{l}\text { Did not get } \\
\text { rTPA/CAC }\end{array}$ & $\begin{array}{l}31.76 \\
(33.67)\end{array}$ & $\begin{array}{c}33.11 \\
(30.65)\end{array}$ & $\begin{array}{c}70.95 \\
(29.17)\end{array}$ & $\begin{array}{c}42.43 \\
(25.46)\end{array}$ & $\begin{array}{c}37.84 \\
(21.75)\end{array}$ & $\begin{array}{c}43.92 \\
(24.58)\end{array}$ & $\begin{array}{c}46.62 \\
(35.92)\end{array}$ & $\begin{array}{c}56.42 \\
(19.46)\end{array}$ & $\begin{array}{c}45.38 \\
(20.65)\end{array}$ \\
\hline $\begin{array}{l}\text { P } \\
\text { Gender: }\end{array}$ & .001 & .018 & .606 & .004 & $<.001$ & .015 & .218 & .044 & .003 \\
\hline Male & $\begin{array}{c}57.58 \\
(34.52)\end{array}$ & $\begin{array}{c}53.22 \\
(33.28)\end{array}$ & $\begin{array}{c}79.30 \\
(23.80)\end{array}$ & $\begin{array}{c}57.88 \\
(26.78)\end{array}$ & $\begin{array}{c}54.17 \\
(26.88)\end{array}$ & $\begin{array}{c}61.36 \\
(27.10)\end{array}$ & $\begin{array}{c}57.95 \\
(31.75)\end{array}$ & $\begin{array}{c}64.96 \\
(23.33)\end{array}$ & $\begin{array}{c}60.76 \\
(22.74)\end{array}$ \\
\hline Female & $\begin{array}{c}29.55 \\
(29.67)\end{array}$ & $\begin{array}{c}42.05 \\
(35.98)\end{array}$ & $\begin{array}{c}69.32 \\
(29.95)\end{array}$ & $\begin{array}{c}51.02 \\
(26.97)\end{array}$ & $\begin{array}{c}51.14 \\
(24.08)\end{array}$ & $\begin{array}{c}48.86 \\
(30.95)\end{array}$ & $\begin{array}{c}48.86 \\
(35.64)\end{array}$ & $\begin{array}{c}60.51 \\
(21.89)\end{array}$ & $\begin{array}{c}50.16 \\
(22.15)\end{array}$ \\
\hline $\begin{array}{l}\text { P } \\
\text { Age group: }\end{array}$ & $<.001$ & .086 & .056 & .177 & .534 & .022 & .165 & .317 & .012 \\
\hline $30-59$ & $\begin{array}{c}68.06 \\
(34.13)\end{array}$ & $\begin{array}{c}56.60 \\
(34.39)\end{array}$ & $\begin{array}{c}82.35 \\
(24.25)\end{array}$ & $\begin{array}{c}63.75 \\
(25.78)\end{array}$ & $\begin{array}{c}63.89 \\
(21.08)\end{array}$ & $\begin{array}{c}64.58 \\
(26.31)\end{array}$ & $\begin{array}{c}56.94 \\
(27.94)\end{array}$ & $\begin{array}{c}66.32 \\
(21.92)\end{array}$ & $\begin{array}{c}65.21 \\
(21.28)\end{array}$ \\
\hline $60-69$ & $\begin{array}{c}52.50 \\
(25.72)\end{array}$ & $\begin{array}{c}51.67 \\
(33.43)\end{array}$ & $\begin{array}{c}75.00 \\
(24.57)\end{array}$ & $\begin{array}{c}58.33 \\
(28.87)\end{array}$ & $\begin{array}{c}52.50 \\
(25.72)\end{array}$ & $\begin{array}{c}62.50 \\
(26.06)\end{array}$ & $\begin{array}{l}55.00 \\
(32.6)\end{array}$ & $\begin{array}{c}65.83 \\
(18.84)\end{array}$ & $\begin{array}{c}59.17 \\
(21.65)\end{array}$ \\
\hline $70-79$ & $\begin{array}{c}33.33 \\
(36.38)\end{array}$ & $\begin{array}{c}42.36 \\
(35.39)\end{array}$ & $\begin{array}{c}69.44 \\
(26.51)\end{array}$ & $\begin{array}{c}48.06 \\
(25.39)\end{array}$ & $\begin{array}{c}51.39 \\
(23.44)\end{array}$ & $\begin{array}{c}50.00 \\
(30.92)\end{array}$ & $\begin{array}{c}53.47 \\
(43.26)\end{array}$ & $\begin{array}{c}67.36 \\
(18.76)\end{array}$ & $\begin{array}{l}51.93 \\
(23.7)\end{array}$ \\
\hline $80+$ & $\begin{array}{c}18.27 \\
(21.86)\end{array}$ & $\begin{array}{l}38.94 \\
(34.7)\end{array}$ & $\begin{array}{c}70.19 \\
(31.64)\end{array}$ & $\begin{array}{c}44.42 \\
(23.55)\end{array}$ & $\begin{array}{c}39.42 \\
(27.54)\end{array}$ & $\begin{array}{c}42.31 \\
(30.63)\end{array}$ & $\begin{array}{c}50.48 \\
(35.62)\end{array}$ & $\begin{array}{c}52.88 \\
(28.13)\end{array}$ & $\begin{array}{c}44.62 \\
(21.62)\end{array}$ \\
\hline $\begin{array}{l}\mathrm{P} \\
\text { Ethnicity: }\end{array}$ & $<.001$ & .191 & .246 & .022 & .002 & .010 & .902 & .069 & .003 \\
\hline Jewish & $\begin{array}{l}46.77 \\
(35.5)\end{array}$ & $\begin{array}{c}58.87 \\
(33.14)\end{array}$ & $\begin{array}{c}78.63 \\
(24.31)\end{array}$ & $\begin{array}{c}59.19 \\
(23.85)\end{array}$ & $\begin{array}{c}55.65 \\
(26.56)\end{array}$ & $\begin{array}{c}60.89 \\
(29.55)\end{array}$ & $\begin{array}{c}59.07 \\
(31.05)\end{array}$ & $\begin{array}{c}64.31 \\
(24.15)\end{array}$ & $\begin{array}{c}60.42 \\
(21.74)\end{array}$ \\
\hline Non-Jewish & $\begin{array}{c}45.65 \\
(36.25)\end{array}$ & $\begin{array}{c}36.14 \\
(32.62)\end{array}$ & $\begin{array}{c}70.45 \\
(30.15)\end{array}$ & $49.46(30.5)$ & $\begin{array}{c}49.46 \\
(24.99)\end{array}$ & $\begin{array}{c}50.54 \\
(28.62)\end{array}$ & $\begin{array}{c}47.55 \\
(35.61)\end{array}$ & $\begin{array}{c}61.14 \\
(21.28)\end{array}$ & $\begin{array}{c}51.28 \\
(24.27)\end{array}$ \\
\hline $\mathrm{P}$ & .872 & $<.001$ & .141 & .076 & .222 & .071 & .076 & .479 & .042 \\
\hline Schooling: & & & & & & & & & \\
\hline Primary & $\begin{array}{c}36.70 \\
(33.32)\end{array}$ & $\begin{array}{c}42.02 \\
(33.22)\end{array}$ & $\begin{array}{l}68.62 \\
(30.6)\end{array}$ & $\begin{array}{c}45.00 \\
(27.62)\end{array}$ & $\begin{array}{c}47.87 \\
(24.91)\end{array}$ & $\begin{array}{c}45.74 \\
(30.09)\end{array}$ & $\begin{array}{c}47.61 \\
(35.32)\end{array}$ & $\begin{array}{c}58.78 \\
(22.71)\end{array}$ & $\begin{array}{c}49.04 \\
(22.97)\end{array}$ \\
\hline Secondary & $\begin{array}{c}52.78 \\
(38.52)\end{array}$ & $\begin{array}{c}57.50 \\
(36.09)\end{array}$ & $\begin{array}{c}78.33 \\
(24.19)\end{array}$ & $\begin{array}{c}63.00 \\
(25.17)\end{array}$ & $\begin{array}{c}57.22 \\
(26.45)\end{array}$ & $\begin{array}{c}66.67 \\
(27.18)\end{array}$ & $\begin{array}{c}61.94 \\
(30.73)\end{array}$ & $\begin{array}{c}66.67 \\
(23.99)\end{array}$ & $\begin{array}{c}63.01 \\
(22.74)\end{array}$ \\
\hline Academic & $\begin{array}{c}55.56 \\
(26.51)\end{array}$ & $\begin{array}{c}44.44 \\
(31.57)\end{array}$ & $\begin{array}{c}85.94 \\
(15.73)\end{array}$ & $\begin{array}{c}61.94 \\
(21.29)\end{array}$ & $\begin{array}{c}55.56 \\
(25.08)\end{array}$ & $\begin{array}{c}58.33 \\
(22.69)\end{array}$ & $\begin{array}{c}52.78 \\
(33.09)\end{array}$ & $\begin{array}{c}65.97 \\
(18.59)\end{array}$ & $\begin{array}{c}59.81 \\
(18.67)\end{array}$ \\
\hline $\begin{array}{l}\mathrm{P} \\
\text { Location of treating } \\
\text { hospital: }\end{array}$ & .043 & .085 & .048 & .002 & .197 & .002 & .119 & .215 & .010 \\
\hline Centre & $\begin{array}{c}48.37 \\
(36.29)\end{array}$ & $\begin{array}{c}61.14 \\
(32.83)\end{array}$ & $\begin{array}{c}76.63 \\
(27.08)\end{array}$ & $\begin{array}{c}59.02 \\
(25.83)\end{array}$ & $\begin{array}{c}61.96 \\
(25.13)\end{array}$ & $\begin{array}{c}61.96 \\
(32.38)\end{array}$ & $\begin{array}{c}58.70 \\
(30.60)\end{array}$ & $\begin{array}{c}63.59 \\
(26.72)\end{array}$ & $\begin{array}{c}61.42 \\
(23.28)\end{array}$ \\
\hline Periphery & $\begin{array}{c}44.92 \\
(34.84)\end{array}$ & $\begin{array}{l}39.84 \\
(33.4)\end{array}$ & $\begin{array}{c}74.19 \\
(26.77)\end{array}$ & $\begin{array}{c}52.34 \\
(27.57)\end{array}$ & $\begin{array}{c}46.48 \\
(24.34)\end{array}$ & $\begin{array}{c}52.34 \\
(26.25)\end{array}$ & $\begin{array}{c}51.17 \\
(35.34)\end{array}$ & $\begin{array}{c}62.89 \\
(19.67)\end{array}$ & $\begin{array}{c}53.00 \\
(22.32)\end{array}$ \\
\hline $\mathrm{P}$ & .616 & .001 & .643 & .201 & .002 & .101 & .247 & .881 & .058 \\
\hline Stroke severity & & & & & & & & & \\
\hline 0 & $\begin{array}{c}57.24 \\
(33.34)\end{array}$ & $\begin{array}{c}60.86 \\
(31.46)\end{array}$ & $\begin{array}{l}77.78 \\
(25.9)\end{array}$ & $\begin{array}{c}65.53 \\
(23.24)\end{array}$ & $\begin{array}{c}61.18 \\
(23.03)\end{array}$ & $\begin{array}{c}63.82 \\
(30.59)\end{array}$ & $\begin{array}{c}62.83 \\
(27.80)\end{array}$ & $\begin{array}{c}67.76 \\
(22.25)\end{array}$ & $\begin{array}{c}64.56 \\
(21.03)\end{array}$ \\
\hline 1 & $\begin{array}{c}44.23 \\
(35.91)\end{array}$ & $\begin{array}{c}51.2 \\
(34.23)\end{array}$ & $\begin{array}{c}78.85 \\
(25.43)\end{array}$ & $\begin{array}{c}53.75 \\
(26.14)\end{array}$ & $\begin{array}{l}51.92 \\
(27.5)\end{array}$ & $\begin{array}{c}57.21 \\
(24.92)\end{array}$ & $\begin{array}{c}59.13 \\
(33.13)\end{array}$ & $\begin{array}{c}64.42 \\
(21.78)\end{array}$ & $\begin{array}{c}57.59 \\
(22.35)\end{array}$ \\
\hline 2 & $\begin{array}{c}34.62 \\
(37.55)\end{array}$ & $\begin{array}{c}17.31 \\
(21.37)\end{array}$ & $\begin{array}{c}57.69 \\
(31.27)\end{array}$ & $\begin{array}{c}45.77 \\
(26.37)\end{array}$ & $\begin{array}{c}38.46 \\
(24.19)\end{array}$ & $\begin{array}{c}44.23 \\
(34.09)\end{array}$ & $\begin{array}{c}26.92 \\
(30.98)\end{array}$ & $\begin{array}{l}49.04 \\
(27.7)\end{array}$ & $\begin{array}{c}39.25 \\
(21.31)\end{array}$ \\
\hline 3 & $\begin{array}{c}25.00 \\
(20.41)\end{array}$ & $\begin{array}{c}23.21 \\
(30.98)\end{array}$ & $\begin{array}{c}67.86 \\
(23.78)\end{array}$ & $\begin{array}{c}26.43 \\
(28.39)\end{array}$ & $\begin{array}{l}42.86 \\
(12.2)\end{array}$ & $\begin{array}{c}32.14 \\
(27.82)\end{array}$ & $\begin{array}{c}23.21 \\
(30.98)\end{array}$ & $\begin{array}{l}55.36 \\
(12.2)\end{array}$ & $\begin{array}{c}37.01 \\
(14.92)\end{array}$ \\
\hline $\mathrm{p}$ & .048 & $<.001$ & .059 & .001 & .025 & .020 & $<.001$ & .054 & $<.001$ \\
\hline Total & $\begin{array}{c}46.36 \\
(35.33)\end{array}$ & $\begin{array}{c}48.75 \\
(34.66)\end{array}$ & $\begin{array}{c}75.23 \\
(26.80)\end{array}$ & $\begin{array}{c}55.14 \\
(26.94)\end{array}$ & $\begin{array}{c}52.95 \\
(25.73)\end{array}$ & $\begin{array}{c}56.36 \\
(29.22)\end{array}$ & $\begin{array}{c}54.32 \\
(33.50)\end{array}$ & $\begin{array}{c}63.18 \\
(22.77)\end{array}$ & $\begin{array}{c}56.52 \\
(23.00)\end{array}$ \\
\hline
\end{tabular}

Table 4 is based on the SF-12v2 Health Domain Scales and is designed to represent a multidimensional concept of quality of life. The abbreviated content for each QoL variable is as follows:

Physical functioning: Moderate level activities, such as moving a table, climbing stairs.

Physical role: $\quad$ You can achieve less than you would like.

Bodily pain: The pain disturbing with normal work/ activities.

General health: $\quad$ Do you rate your health as: excellent, very good, good, fair, or poor?

Vitality:

Social functioning: How often do health problems interfere with social activities?

Emotional role: $\quad$ You can achieve less than one would like, perform desired activities less carefully.

Mental health: $\quad$ Feel calm and peaceful/downhearted and depressed.

\section{DISCUSSION}

The overall picture that emerges from SDC Tables 1-4 is that four groups suffer the poorest post-discharge outcomes - those who are not treated with rTPA/CAC, women, the oldest age group, and residents of Israel's peripheral regions, who in the case of the North region are mainly non-Jewish Israeli-Arabs. What is remarkable is that members of all four groups suffer, overall, worse outcomes on every one of the thirteen post-stroke QoL components without exception. One may conclude from this that these thirteen items do indeed represent a multidimensional measurement of their quality of life. 
The reason why stroke patients who did not receive TPA/CAC should suffer worse QoL outcomes is fairly evident. It would have been useful to cite statistics of causation here between the receipt of rTPA/CAC and subsequent wellbeing variables, but these statistics were beyond the scope of the present study. However, the causative direction from receipt of rTPA/CAC to improved health and functioning seems fairly self-evident and the correlation has been established by many earlier studies [2]-[4].

More interesting are the other three groups because each suffers worse QoL outcomes for different reasons.

\section{A. Women}

In Table 4 the largest QoL gap by far between men and women is that for social functioning, and, after that, for physical functioning. This may reflect the fact that Israeli women are, on average, significantly older than men when they suffer a stroke and that their strokes are severer. Perhaps these elderly women see themselves as the homemaker and social organizer of their family, roles obviously severely impaired by the physical consequences of their stroke. Israeli women who suffer strokes have been found to perceive their quality of life thirteen percentage points lower than men (controlling for functional status and age [5]. Maybe also women do not expect to suffer a stroke - for stroke is widely perceived to be a male problem - and so find it more painful to cope with. It is likely too that the women, being older when they get their stroke, will pay the price for age discrimination in hospital stroke care - see the following section).

Although in terms of hospital care women suffer no gender discrimination, our study found that they are markedly less likely to be offered residential rehabilitation care than men (29\% vs. $43 \%$ ). We know that although he age-standardized stroke incidence rate for Israeli men is $43 \%$ higher than that for women [6] Israeli women, overall, suffer the severer strokes and the greater disability [7]. Is this the reason for their lower referral rate to rehabilitation? Or could it be that more women than men decline to go away from home for rehabilitation care? This seems to be a fit issue for further research.

\section{B. The Elderly}

In Table 4 the largest gap by far between the oldest and the youngest age group of stroke patients is that for physical functioning. This is presumably because older age groups tend to suffer severer strokes. Other gaps are markedly smaller. Unsurprisingly, the loss of physical ability is hard to bear.

Quantitative analysis in the present study showed that older stroke patients were less likely than the younger to be receive the rTPA and/or CAC therapies (although the finding fell short of statistical significance). The qualitative interview of hospital staff seems to have uncovered one of the reasons for this. Almost $70 \%$ of interviewees admitted to adopting different degrees of discrimination between older and younger patients, to the disadvantage of the elderly, both as regards acute care and rehabilitation care. Typical comments - which did not reflected their hospital's policy or performance [8], [9] — were: "To be honest I've noticed that with respect to the older patients...it's as though the notion of transferring them to rTPA doesn't even cross your mind." "When the patient is a younger man you take more interest, you're more on the ball" "Some rehabilitation facilities won't even take in the over 60s."

This finding confirms Israel's 2013 national stroke survey of hospitalized stroke patients which registered that "Inhospital treatments were performed less frequently among older patients with ischemic events" [1], [10]. This finding goes directly against the guidelines issued by the Israeli Neurological Association for the administration of thrombolytic and invasive stroke treatments which lay down that "there are no contraindications by patient age for the administration of these treatments although care needs to be taken with respect to the danger of haemorrhages and other complications".

The residents of Israel's peripheral regions (both Arabs and Jews) are the chief patients of Israel's regional inequalities in stroke care provision and accessibility. The findings of the present study make rather stunning reading. $86 \%$ of Central region stroke patients were administered rTPA/CAC compared to $49 \%$ of Northern stroke patients. Of all the patients who did not win through to rTPA/CAC no less than $84 \%$ were treated in North region hospitals. In other words, treatment delays and other delivery inadequacies are a prominent problem of Israel's northern region (and other peripheries). Disparities in stroke-care access and provision translate, as Tables 1-4 illustrate, into higher rates of postdischarge disability, impaired physical and social functioning, and a lower quality of life.

Furthermore, the present study found that $56 \%$ of Central region residents are referred on hospital discharge to residential rehabilitation but only $23 \%$ of Northern residents; Rehabilitation beds are in such short supply (and also of inferior quality) in the North that $70 \%$ of post-discharge stroke patients there refuse to take up a bed, even if one can be found, because of its distance from their home [9].

Yet these disparities in healthcare access and availability are not thought by Israeli scholars (and the author of the present study agrees with them) to be the outcome of any ethno-religious discrimination, neither at hospital nor governmental level, but the result of a nationwide long-term neglect of low-income population groups [11], [12]. The disparities of provision reflect the lack of affirmative action to redress the inherent disadvantages of low-income population groups in geographically peripheral regions in accessing healthcare.

The authors believe that many variables combine to produce this socio-geographic disparity of access - the Central region has better-equipped treatment facilities and more neurologists, a better ambulance service, shorter distances from patients' homes to the nearest treatment centre, a population of higher socioeconomic and educational status, with higher awareness of stroke symptom urgency, and better ability to communicate with doctors. (see Table 5).

However, we also must take into account that QoL outcome indicators, such as those deployed for Tables 3-4, are considerably affected by the behaviour patterns and lifestyles which stroke patients bring with them from their earlier life. Israel's 2014-15 national stroke survey showed the age-standardized stroke incidence rate among IsraeliArabs to be no less than $43 \%$ higher than the rate for Israeli Jews [6]. Israeli-Arabs fall victim to stroke at younger ages than Israeli Jews and more of them suffer severer strokes than 
Israeli Jews, significantly because they score much higher on the risk factors for stroke (smoking, healthy lifestyle, etc.) and the background illnesses which frequently accompany stroke [13] and because they have lower awareness of stroke symptoms and their urgency. Thus, the state of affairs in Israel's North region might be fairly summarized thus: The Israeli-Arab population in the North is exceptionally vulnerable to stroke but lives in an area which is served by a stroke treatment system objectively much inferior to that in the country's centre on all treatment components, from prehospital ambulance service thought to post-discharge rehabilitation.

TABLE 5: COMPARING ISRAEL'S CENTRAL AND NORTHERN REGIONS BY SOCIOECONOMIC AND HEALTHCARE PROVISION INDICATORS [16]-[18]

\begin{tabular}{|c|c|c|}
\hline & $\begin{array}{l}\text { Central Region } \\
\text { (inc. Tel Aviv) }\end{array}$ & $\begin{array}{c}\text { North Region } \\
\text { (does not include } \\
\text { Haifa) }\end{array}$ \\
\hline Type of area & Urban & Mostly rural \\
\hline Socio-economic status & High & Mostly low \\
\hline Social service provision & Good & Low \\
\hline All doctors per 1000 persons & 3.4 & 2.3 \\
\hline All nurses per 1000 persons & 4.7 & 4.4 \\
\hline $\begin{array}{l}\text { Hospital beds per } 1000 \\
\text { persons }\end{array}$ & 1.71 & 1.57 \\
\hline $\begin{array}{l}\text { Number of rehabilitation } \\
\text { beds }\end{array}$ & 650 & 143 \\
\hline $\begin{array}{l}\text { Number of hospitals } \\
\text { providing rTPA }\end{array}$ & 8 & 4 \\
\hline $\begin{array}{l}\text { Number of hospitals } \\
\text { providing Cerebral Artery } \\
\text { Catheterization }\end{array}$ & 5 & 1 \\
\hline
\end{tabular}

\section{CONCLUSIONS}

Post-AIS physical and social disability must and can be seriously reduced for stroke is the major cause of disability in old age and the damage done to familial and social relationships is possibly the gravest harm resulting from strokes. Disability is also caused when the environment fails to adapt to people's needs [14]. and when societal and governmental institutions do not do enough to support stroke patients and remove obstacles to their social integration [15].

The present study was designed and structured on an overall unidirectional model whose start-point is the preexisting risk factors which combine to cause AIS; the next phase is the illness and the medical and rehabilitational response to it. The third phase of the model is the patient's post-discharge clinical outcomes, functional status, and quality of life, which themselves are the product and outcomes of the second illness-and-treatment phase. The concept underpinning this model is that sociodemographic variables, risk factors and initial functional status all combine into the probability of an individual suffering an AIS and influence both the chances of stroke patients receiving the appropriate treatment and the likelihood of this treatment succeeding. That regional stroke care access and provision disparities translate into higher rates of post-discharge disability, impaired physical and social functioning, and a lower quality of life for discharged stroke patients in the Northern periphery demonstrates that the present study's unidirectional model is correct.

It is clear that the effectiveness of healthcare improvement by the deployment of additional care quality indicators is closely associated with the socio-demographic and socioeconomic status of the populations which the healthcare system is serving. That the groups shown by the present study to suffer the worst post-discharge QoL outcomes come to this state for different constellations of reasons implies that there needs to be a specifically tailored response to the divergent problems of each population group. Any stroke care improvement initiative must, in its very design stage, familiarize itself with the relevant differences in healthcare behaviour culture and situation between the population groups whom the improvement initiative hopes to benefit. The effective implementation of stroke quality care indicators will also rely heavily on closing the gaps on provision between central and peripheral areas.

Two obvious and relatively uncostly directions for action in Israel are to expand and improve the rehabilitation care network and to combat the age discrimination in hospital stroke treatment.

\section{LIMITATIONS OF THE STUDY}

The chief limitation of the present study is the composition of its sample in comparison to a fully representative national sample. By design, the study sample contains a disproportionately large component of non-Jews and geographically peripheral residents. From this flows that it is younger than a national sample $(31 \%$ v. $19 \%$ in the $30-59$ age group), less well-educated ( $71 \%$ of its Israeli-Arab subjects have primary schooling only), and more deprived in terms of income and access to local stroke care provision.

The second main departure from a representative national sample is that, also by design, an estimated $50 \%$ of all stroke patients across the country are not represented. The study's research population was restricted to stroke patients who reach hospital within 210 minutes of symptom onset, this in order to measure the rate of application of the rTPA/CAC therapies within their effective time-window.

Thus, the study sample represents to a considerable extent stroke patients who are more aware of stroke symptoms and the urgency of their treatment and who have the means to get to hospital quickly — although many North region residents would not qualify on those terms.

Because the differences between the study sample and a national sample in terms of educational level, access to provision, stroke awareness, and so on pull in different directions in it is hard to be exact as to the size of bias in the study's findings in comparison to a representative national sample. The only warning to be given is to stay aware of the nature of the study sample when considering each finding.

\section{ACKNOWLEDGMENT}

I wish to express here my grateful thanks to Prof. Carmel Armon and Dr. Itzhak Kimiagar who made it possible for me to find, recruit and interview patients and staff and to accomplish all the many other tasks necessary to carrying out the present study. 


\section{REFERENCES}

[1] Annat A-Z, Ronit P, Micha M, et al. The National Program for Quality Indicators in Hospitals in Israel Report for 2013-2014 [in Hebrew]. Jerusalem; https://www.health.gov.il/PublicationsFiles/Quality_National_Prog_2 013-14.pdf.

[2] Saver JL, Fonarow GC, Smith EE, et al. Time to treatment with intravenous tissue plasminogen activator and outcome from acute ischemic stroke. JAMA - J Am Med Assoc. 2013. doi:10.1001/jama.2013.6959.

[3] Saver JL, Gornbein J, Grotta J, et al. Number needed to treat to benefit and to harm for intravenous tissue plasminogen activator therapy in the 3- to 4.5-hour window Joint outcome table analysis of the ECASS 3 trial. Stroke. 2009. doi:10.1161/STROKEAHA.108.543561.

[4] Wardlaw JM, Murray V, Berge E, Del Zoppo GJ. Thrombolysis for acute ischaemic stroke. Cochrane Database Syst Rev. 2009. doi:10.1002/14651858.CD000213.pub2.

[5] Racheli D, Dalit L-G. Israeli study: After a stroke women suffer poorer

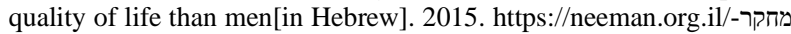
ישראלי-לאחר-שבץ-מוחי-נשים-סובלות-מ.

[6] Amber Z, Carmit L, Amit R, Rita D, Yael H, Tammy S. National Registry of Strokes in Israel Report for 2015-2014 [in Heabrew]. Jerusalem; 2017. https://www.health.gov.il/PublicationsFiles/stroke_registry_report_20 14-2015.pdf.

[7] Nihama G, Miriam A, Ziona H. Leading Causes of Death 2000-2014 in Israel [in Hebrew]. Jerusalem; 2017. https://www.health.gov.il/NewsAndEvents/SpokemanMesseges/Pages /07062017_3.aspx.

[8] Armon C, Wainstein J, Gour A, et al. CT-guided thrombolytic treatment of patients with wake-up strokes. eNeurologicalSci. 2019. doi:10.1016/j.ensci.2019.02.002.

[9] Kimiagar I, Kalmanovich-Avnery S, Gonen OM, et al. Effect of the 2013 AHA/ASA guidelines on TPA use in acute ischemic stroke at Assaf Harofeh Medical Center in Israel. J Neurol Sci. 2016. doi:10.1016/j.jns.2016.08.038.

[10] Tanne D, M.Bronstein N. National Acute Stroke ISraeli 2013 Registry.; 2013. https://cdn.mednet.co.il/2019/05/israel-neurology-NASIS2013.pdf.

[11] Ema A, Shlomit A. Inequality in Health and Dealing with It [in Hebrew]. Jerusalem; 2016. https://www.health.gov.il/publicationsfiles/inequality-2016.pdf.

[12] Ema A. Inequality in Health and Dealing with It: The Welfare of Residents in the Regions of Israel [in Hebrew]. Jerusalem; 2015.

[13] Koton S, Tsabari R, Molshazki N, et al. Burden and Outcome of Prevalent Ischemic Brain Disease in a National Acute Stroke Registry. Stroke. 2013. doi:10.1161/STROKEAHA.113.002174.

[14] Meir H, Eli L, Joseph K. Social Work in Israel [in Hebrew]. (Hakibbutz Hameuchad, $\quad$ ed.). Tel-aviv; 2013. https://kotar.cet.ac.il/KotarApp/Viewer.aspx?nBookID=100252788.

[15] Robert B, John C, Jenny S. What You Really Need to Know About Caring for Someone After a Stroke. Lebhar-Friedman books; 2000.

[16] Akka-Zohar A, Freedman L, Mandel M, et al. Israeli Program of Health Care Quality Indicators (IPHCQI)[in Hebrew].; 2016. https://www.health.gov.il/PublicationsFiles/Quality_National_Prog_2 013-2015.pdf.

[17] Averbuch E, Avni S. Inequality in Health and Dealing with It in Hebrew].; https://www.health.gov.il/publicationsfiles/inequality-2016.pdf.

[18] Hell S, Haklay Z. Hospital Beds and Licensing Positions [in Hebrew].; 2016. https://www.health.gov.il/publicationsfiles/beds2016.pdf. 